\title{
"Integral risk assessment to optimize expenses for occupational safety measures at a machine-building enterprise"
}

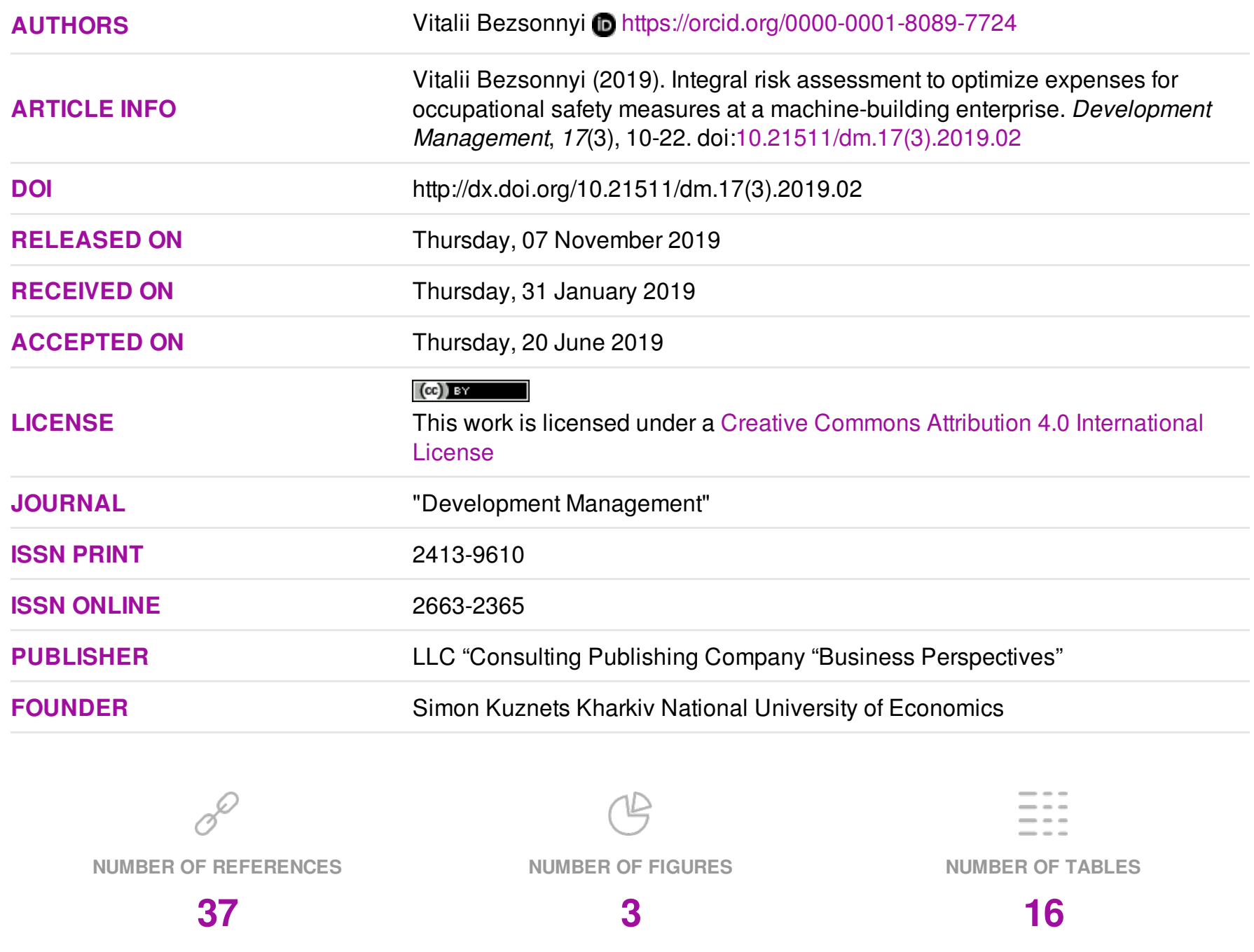

(C) The author(s) 2023. This publication is an open access article. 


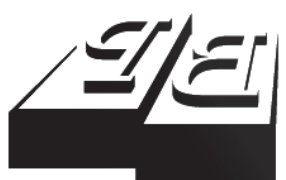

BUSINESS PERSPECTIVES

Publisher

LLC "CPC "Business Perspectives" Hryhorii Skovoroda lane, 10, Sumy, 40022, Ukraine www.businessperspectives.org

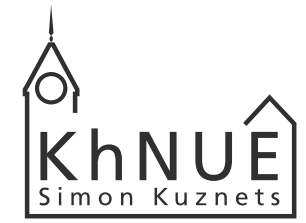

S. KUZNETS KHNUE

Founder

Simon Kuznets Kharkiv National University of Economics, Nauky avenue, 9-A, Kharkiv, 61166,

Ukraine

http://www.hneu.edu.ua/

Received on: $31^{\text {st }}$

of January, 2019

Accepted on: $20^{\text {th }}$

of June, 2019

(C) Vitalii Bezsonnyi, 2019

Vitalii Bezsonnyi, Ph.D., Senior Lecturer of the Department of Environmental Technologies,

Ecology and Safety of Life,

Simon Kuznets Kharkiv National University of Economics, Ukraine

\section{(c) (1)}

This is an Open Access article, distributed under the terms of the Creative Commons Attribution 4.0 International license, which permits unrestricted re-use, distribution, and reproduction in any medium, provided the original work is properly cited.

\title{
INTEGRAL RISK ASSESSMENT TO OPTIMIZE EXPENSES FOR OCCUPATIONAL SAFETY MEASURES AT A MACHINE-BUILDING ENTERPRISE
}

\begin{abstract}
In the absence of uniform and unified requirements for the assessment of industrial risks at an enterprise, the system approach remains the only tool for a comprehensive assessment of the workplace safety. Implementation of Occupational Safety and Health (OSH) system involves identifying, analyzing and reducing risks at the workplace. The purpose of the article is to calculate the minimum expenses for occupational safety measures and minimize production risks identified through the developed procedure for analyzing the hazards of the machine-building enterprise. The research methodology is based on the integrated use of qualitative and quantitative approaches to risk assessment, namely, structured assessment and integral assessment using the "rucksack problem" optimization model. The study identifies the risks that are most common and the most serious ones. The procedure of risk reduction is proposed, which is to determine the minimum costs for achieving each of the integral assessments for the machine-building enterprise. The practical value of work consists in the ability to directly apply the developed methodology for risk assessment at the enterprises of the machine-building industry, and to easily adapt the risk assessment procedure to other conditions.
\end{abstract}

Keywords

JEL Classification

В.Л. Безсонний (Україна) industrial risk, complex risk assessment, integral risk assessment, "rucksack problem" model, structured risk assessment

J17, C61, L23

\section{ІНТЕГРАЛЬНА ОЦІНКА РИЗИКУ ДЛЯ ЦІЛЕЙ ОПТИМІЗАЦІЇ ВИТРАТ НА ЗАХОДИ 3 ОХОРОНИ ПРАЦІ МАШИНОБУДІВНОГО ПІДПРИЕМСТВА}

\section{Анотація}

В умовах відсутності єдиних та уніфікованих вимог до оцінки виробничих ризиків на підприємстві системний підхід залишається єдиним інструментом комплексного оцінювання стану безпеки праці. Використання системи управління охороною праці передбачає ідентифікацію ризиків на робочому місці, їх аналіз та зниження. Метою роботи є розрахунок мінімальних витрат на заходи 3 охорони праці та мінімізацію виробничих ризиків, виявлених за допомогою розробленої процедури аналізу небезпек на машинобудівному підприємстві. Методологія дослідження базується на комплексному використанні якісного та кількісного підходів до оцінки ризику, а саме структурованої оцінки та інтегральної оцінки 3 використанням оптимізаційної моделі «пакування рюкзака». В результаті дослідження встановлені ризики, які є найпоширенішими та ризики, що є найтяжчими. Запропоновано процедуру зниження ризиків, що полягає у визначанні мінімальних витрат на досягнення кожної з інтегральних оцінок для машинобудівного підприємства. Практична цінність роботи полягає у можливості прямого застосування розробленої методики оцінки ризиків на підприємствах машинобудівної галузі, та у легкій адаптації процедури оцінки ризиків для інших умов.

\section{Ключові слова}

Класифікація JEL виробничий ризик, комплексне оцінювання ризиків, інтегральна оцінка ризику, модель «пакування рюкзака», структурована оцінка ризиків

J17, C61, L23 


\section{ВСТУП}

Ризик є природною складовою життя, що супроводжує людину в усіх сферах ï діяльності, в одних випадках він може бути великим і бути причиною аварій або нещасних випадків на роботі та причиною професійних захворювань, в інших - ризик менше, і його наслідки не такі небезпечні, наприклад, невелика травма або незначні матеріальні збитки.

Серед факторів ризику, яких зазнає сучасна людина, важливе місце посідає ризик втрати здоров’я і працездатності внаслідок професійної діяльності. Для умов сучасного виробництва характерне використання як токсичних речовин, так і різноманітних випромінювань, робототехніки, поточних ліній, значна частина робіт є нервово напруженою, в умовах підвищеної загазованості та запиленості.

Це збільшує ймовірність небезпеки нещасних випадків та професійних захворювань для робітників.

Управління охороною праці на основі системного підходу спирається на ідентифікацію та оцінку ризику травматизму в умовах робочої обстановки [26].

Для запобігання травматизму та підвищення рівня безпеки праці в Україні, відповідно до статті 13 Закону України «Про охорону праці», на кожному підприємстві вимагається впровадження системи управління охороною праці. Роботодавець має забезпечити дотримання вимог законодавства у галузі охорони праці та обладнати робочі місця відповідно до нормативно-правових актів [28]. За порушення зазначених у законодавстві вимог безпосередню відповідальність несе роботодавець. Однак впровадження вимог Закону у практику господарювання відбувається повільно чи недостатньо професійно, що гальмує отримання ефективних результатів. Тож, виникає необхідність розробки нових та удосконалення вже наявних інструментів впровадження статей Закону України «Про охорону праці», і насамперед це стосується оцінювання ризиків на підприємстві.

\section{1. ЛІТЕРАТУРНИЙ ОГЛЯА}

Управління ризиками є актуальним питанням в дослідженні промислової безпеки, про що свідчить значна кількість робіт у цьому напрямку $[19,23,36]$. Зокрема, в роботі [13] розглядається питання мінімізації наслідків виробничого травматизму та наводиться відповідна модель прийняття рішення щодо управління ризиками для сторін трудового договору. Проведений аналіз робіт показує, що найбільш поширеними методами, що використовують для аналізу показників охорони праці $\epsilon$ детерміністичні групи методів та імовірнісно-статистичні математичні моделі $[3,27,31,32]$. Системний підхід та комплексування різних методів за умов відсутності єдиної універсальної концепції дослідження проблем безпеки праці робить можливим найоптимальнішим чином планувати підприємству працеоохоронну політику та забезпечувати належні умови праці відповідно до законодавства [17, 29, 30, 37]. Важливим фактором для формування об'єктивної інформаційної бази дослідження безпеки праці та виробничого травматизму є ретельність підготовки та наповненість відповідних статистичних форм та звітності $[24,25,27,32]$. Методологічне та науково-практичне підгрунтя дослідження питань безпеки праці та травматизму заклали такі дослідники, як Березуцький, Девисилов, Венедіктов, Третьяков, Гогіташвілі, Зацарний, Костенко, Кропивницький, Лисюк, Келемен, Рубан та інші. У більшості випадків дослідники доходять висновку про доцільність попереднього використання результатів моделювання при впровадженні заходів, що спрямовані на регулювання взаємодії роботодавця та працівника, у роботі [1] здійснено аналіз ризиків при експлуатації вантажопідіймальних механізмів. При дослідженні ризиків використовувався метод відмов. Автори [2] наводять аналіз та характеристику існуючих кількісних та якісних методів оцінки ризику небезпечних промислових об’єктів як на Україні, так і за кордоном. В роботі [4] розглядають задачу зниження ступеню небезпеки ризикової події з мінімальними витратами, що досягається заходами двох типів - перші знижують ймовірність настання ризикової події, а другі - знижують збиток при настанні ризикової події. Баскаков, Єфімов та Сенаторов [6] 
сформульовали системні принципи та запропоновали методика оцінки ризиків аварій та нещасних випадків на вуглевидобувних підприємствах. У статті [5] наголошується на необхідності формування культури управління ризиками на підприємствами як необхідної умови завчасного виявлення, оцінки та зниження ризиків, а також відкритої комунікації про ризики. Моделі, методи та механізми управління регіональною безпекою, що розглянуті в роботі [11], дозволяють не тільки проводити оцінку ефективності діючої системи економічних механізмів управління ризиком, але й розробляти науково-обгрунтовані рекомендації з їі вдосконалення з урахуванням регіональних властивостей. Ветошкин та Таранцева [33] розглянули концепцію екологічної та техногенної безпеки, навели методи аналізу техногенного ризику, підготували рекомендації щодо застосування основних положень безпеки технічних систем. У статті [34] проаналізовано вимоги ISO 9001:2015 та ISO 14001:2015 стосовно аналізу ризиків. В роботі [35] розглянуто сучасні методи оцінки умов праці та безпеки робіт на промисловому підприємстві при реалізації європейських нормативів в області охорони праці. Авторами [18] розглянуто теоретичні основи питання управління ризиками. У статті Костенко [24] проаналізовано механізми створення математичних моделей оцінки ризиків технологічних процесів. Основою цього підходу є використання індуктивних алгоритмів для математичного моделювання багатопараметричних даних при управлінні безпекою праці на підприємстві. Денисенко та Дяченко [12] розроблена методика оцінки виробничого ризику, яка дозволяє виявити динаміку основних видів його прояву. Міжнародні документи [21] та [22] були розроблені для здійснення інтеграції систем менеджменту якості та навколишнього середовища в організаціях за наявної в них потреби. Стандарт [15] і супутній стандарт [16] були розроблені у відповідь на вимоги споживачів створити загальновизнаний стандарт для системи менеджменту професійної безпеки і здоров'я, на підставі якого можуть бути оцінені і сертифіковані їх системи менеджменту.

3 проведеного аналізу літературних джерел є очевидним, що підходи до визначення поняття ризику, в тому числі і професіонального, включають в себе, крім класичної ймовірності настання несприятливої події, також і пов’язані з цим збитки, в тому числі і здоровю, а також і оцінки матеріальних наслідків, що враховують витрати на відновлення здоров’я, матеріальних цінностей та робочого середовища. На жаль, наша держава характеризується високим рівнем техногенних ризиків, виробничого травматизму, професійних захворювань, і відповідно низькою культурою безпеки праці.

У зв’язку з цим постає питання розробки інтегральної оцінки ризиків з метою оптимального управління витратами на заходи та засоби з охорони праці, враховуючи всю сукупність соціально-економічних факторів, в тому числі і шляхом моделювання [7-10].

\section{2. МЕТА ДОСЛІДЖЕННЯ}

Метою роботи є формування комплексної процедури аналізу виробничих ризиків, що включає їх ідентифікацію, інтегральну оцінку та вибір заходів з мінімальними витратами щодо забезпечення допустимого рівня безпеки в процесі роботи машинобудівного підприємства.

Для досягнення поставленої мети необхідно вирішити наступні задачі:

- ідентифікувати та проаналізувати існуючі ризики на ДП «Завод «Електроважмаш» і здійснити їх класифікацію методом структурованої оцінки ризиків;

- розробити процедуру інтегральної оцінки ризику на основі моделі «пакування рюкзака».

\section{3. МЕТОДИ ДОСЛІДЖЕННЯ}

В роботі в комплексі розглядаються якісні (структурована оцінка) та кількісні (інтегральна оцінка 3 використанням моделі «пакування рюкзака») методи оцінки ризиків. Оцінка ризиків здійснювалася відповідно до Міжнародного стандарту «Системи управління охороною здоров’я і безпекою персоналу. Вимоги» [31]. При проведенні робіт з ідентифікації небезпек, оцінки ризиків та управління ризиками розглядалися: 
- постійні операції, для проведення яких призначене робоче місце, періодичні та епізодичні операції, зокрема, такі як чистка та ремонт, пуск і зупинка, а також потенційні аварійні ситуації, споживання продукції або послуг, що поставляються іншими організаціями;

- діяльність усього персоналу, що має доступ до робочого місця (а також відвідувачів);

- обладнання на робочому місці.

Перераховані вище фактори розглядалися у підрозділах за наступних ситуацій:

- нормальні (робочі) умови;

- анормальні умови (пуск, зупинка, ремонт і т.д.);

- аварійні умови і інциденти.

По завершенню процесу ідентифікації небезпек та оцінки ризиків структурні підрозділи підприємства мали повне уявлення стосовно наявних небезпек для працівників.

При проведенні ідентифікації небезпек визначався перелік робочих місць таким чином, щоб отримати максимально достовірну інформацію про небезпеки, що існують в даному структурному підрозділі. Для робочих місць із ідентичним характером виконуваних робіт і аналогічними умовами праці вибиралося одне-два робочих місця.

Вибрані робочі місця структурного підрозділу представляли всі типи виконуваних в підрозділі робіт, усі професії (особливо пов'язані з підвищеною небезпекою).

В обов’язковому порядку проводилася ідентифікація небезпек для тих працівників, які мають не постійні робочі місця (водій електрокара, автонавантажувача, зварювальник, вантажник, стропальник і т.п.), а також для тих працівників, які найбільш часто фігурують в журналах контролю стану охорони праці в якості «порушників» виробничої дисципліни.

При проведенні спостережень та співбесід із працівниками відслідковувалися найважливіші фактори, що впливають на безпеку робочого місця: виробничий процес; обладнання робочого місця; безпека праці при роботі на виробничому обладнанні; фактори навколишнього середовища на робочому місці; ергономічні чинники; проходи і проїзди; можливості для порятунку і надання першої допомоги.

Методика структурованої оцінки ризиків. Первинна оцінка ризиків і небезпек проводиться 3 використанням методу структурованої оцінки.

Оцінка ризику Р базується на трьох параметрах і визначається за формулою:

$P=B \times \Psi \times T$,

де $P$ - ступінь ризику, $B$ - імовірність виникнення небезпеки, несприятливою події, що загрожує життю, здоров'ю людини, обладнанню підприємства, визначається за Таблицею 1 , при оцінці ризиків, пов'язаних із впливом шкідливих факторів, ймовірність існування ризику визначається за Таблицею 2, Ч - частота, з якою працівники піддаються небезпеці, впливу шкідливих та небезпечних факторів, визначається за Таблицею 3, T - наслідки, оцінюються за Таблицею 4.

На підставі отриманої оцінки у відповідності до Таблиці 5 проводиться аналіз ризиків та визначається необхідність проведення коригуючих дій. 
Таблиця 1. Показник імовірності існування ризику $B$, оцінюється при впливі на працівників небезпечних виробничих факторів

\begin{tabular}{|c|c|c|}
\hline Значення & Ступінь імовірності & Періодичність виникання ризику \\
\hline 10 & Дуже висока & Щомісячно \\
\hline 6 & Висока & Можливо впродовж тижня \\
\hline 3 & Середня & Можливо впродовж місяця \\
\hline 1 & Мала & Можливо впродовж року \\
\hline 0,5 & Дуже мала & Впродовж терміну експлуатації \\
\hline 0,1 & Практично не можлива & Теоретично можливо, практично ні \\
\hline
\end{tabular}

Таблиця 2. Показник імовірності існування ризику $B$, оцінюється при впливі на працівників шкідливих виробничих факторів

\begin{tabular}{l|l|l}
\hline 3начення & Ступінь імовірності & Перевищення ГДК, інших гігієнічних нормативів (разів) \\
\hline 10 & Дуже висока & 20 \\
\hdashline 6 & Висока & $10,1-20$ \\
3 & Середня & $6,1-10$ \\
\hline 1 & Мала & $3,1-6$ \\
0,5 & Дуже мала & $1,1-3$ \\
0,1 & Практично не можлива & $\leq 1$ \\
\hline
\end{tabular}

Таблиця 3. Показник частоти впливу Ч

\begin{tabular}{|c|c|c|}
\hline Значення & Характеристика & Періодичність роботи в небезпечній зоні \\
\hline 10 & Постійно & Впродовж зміни постійно \\
\hline 6 & Регулярно & Впродовж зміни періодично \\
\hline 3 & Періодично & Декілька разів на тиждень \\
\hline 2 & Іноді …............ & Декілька разів на місяць \\
\hline 1 & 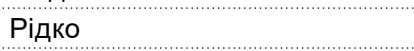 & Декілька разів на рік \\
\hline 0,5 & Дуже рідко & Менше одного разу на рік \\
\hline
\end{tabular}

За ризиками, що отримали оцінку 100 балів і вище, розробляються додаткові профілактичні заходи. Після цього проводиться аналіз ризиків з урахуванням розроблених заходів та попереджувальних дій. Профілактичні заходи, що вимагаються законодавством або іншими обов’язковими до виконання документами, приймаються незалежно від результатів оцінки ризику.

Таблиця 4. Показник тяжкості наслідків $T$

\begin{tabular}{l|l|l}
\hline \multicolumn{1}{c}{ Значення } & Категорія наслідків & Характеристика тяжкості наслідків \\
\hline 40 & Крупна аварія & Груповий нещасний випадок (два і більше смертельних випадків) \\
15 & Дуже значні & Один смертельний випадок \\
\hdashline 7 & Значні & Іевалідність, стійка втрата працездатності \\
3 & Серйозні & Тимчасова або часткова втрата працездатності \\
1 & Незначні & $\begin{array}{l}\text { Незначні травми, з наданням першої медичної допомоги без втрати } \\
\text { працездатності }\end{array}$ \\
\hline
\end{tabular}

Таблиця 5. Аналіз ризиків та рекомендовані дії

\begin{tabular}{|c|c|c|}
\hline Оцінка ризику & Ступінь ризику & Дiï \\
\hline Більше 400 & $\begin{array}{l}\text { Дуже високий } \\
\text { (недопустимий) }\end{array}$ & Роботу припинити або не розпочинати до зменшення ступеню ризику \\
\hline $300-400$ & Високий & $\begin{array}{l}\text { Розробити порядок організації робіт, прийняти заходи зі зменшення ризику в } \\
\text { термін, що не перевищує трьох місяців }\end{array}$ \\
\hline $100-300$ & Значний & Впровадити заходи зі зменшення ризику в терміни, визначені цілями \\
\hline До 100 & Допустимий & $\begin{array}{l}\text { Дотримуватися загальних правил з охорони праці (діючі нормативно-правові } \\
\text { акти) }\end{array}$ \\
\hline
\end{tabular}


Методика комплексного оцінювання для визначення інтегральної оцінки ризику. Модель «пакування рюкзака». Існують три стратегії ризику: прийняття ризику, уникнення ризику, управління ризиком. Необхідно вміти оцінювати ступінь ризику як кількісними, так і якісними методами з метою мінімізації його впливу на працюючих.

Ступінь небезпеки ризикової події залежить як від ймовірності його настання, так і від величини збитку при її настанні.

Чим вища ймовірність настання і чим більший збиток, тим більший ступінь небезпеки. Зазвичай ступінь небезпеки визначається як добуток ймовірності на збиток (очікуваний збиток)

$D=p \times S$,

де $D$ - ступінь небезпеки, ризик, $p$ - ймовірність настання ризикової події, $S$ - збиток.

Однак, застосовуються також і інші формули (1), що якісно відображають ріст ступеню небезпеки при зростанні ймовірності та збитку. Враховуючи певну грубість оцінок ймовірності та збитку, перейдемо до дискретних шкал.

Для визначення ступеню небезпеки визначимо матрицю, строки якої відповідають різним рівням імовірності, а стовпчики - різним рівням збитку. В клітинках матриці містяться значення ступеню небезпеки. В подальшому, для спрощення розрахунків будемо розглядати тільки три рівня ймовірності та збитку - мінімальний, середній і високий.

Очевидно, що ступінь небезпеки складних ризиків визначається на основі простих ризиків. Позначимо $P_{i}, S_{i}$ та $d_{i}$ відповідно ймовірність, збиток та ступінь небезпеки $i$-го простого ризику для деякого складного ризику. Тоді ступінь небезпеки складного ризику дорівнює

$$
D=\sum_{i} d_{i}=\sum_{i} P_{i} S_{i} .
$$

Подамо це у вигляді

$D=P \times S$,

де $S=\sum_{i} S_{i}$.

Звідси отримуємо:

$p=\frac{D}{S}=\frac{\sum P_{i} S_{i}}{\sum S_{i}}$.

Поставимо здачу знизити ступінь небезпеки ризикової події з мінімальними витратами. Зниження ступеню небезпеки досягається за рахунок заходів двох типів. Заходи першого типу зменшують імовірність настання ризикової події, а заходи другого типу знижують збитки при настанні ризикової події. Приймемо для початку, що заходи першого та другого типів не пересікаються. Нехай $є n$ заходів першого типу. Позначимо $a_{i}$ - зменшення ймовірності $P$ при проведенні $i$-го заходу, $b_{i}$ - витрати на проведення $i$-го заходу. Далі позначаємо $A_{1}$ - величину зниження ймовірності, необхідну для переводу даного показника в категорію мінімального ризику, $A_{2}$ - величину зниження ймовірності, необхідну для переводу показника в категорію середнього ризику. Позначимо $x_{i}=1$, якщо $i$-й захід увійшов у програму зниження ризику, $x_{i}=0$ в іншому випадку. 
Постановка задачі:

Визначити $x_{i}, i=\overline{1, n}$, такі, що $\sum_{i} b_{i} x_{i} \rightarrow \min$, при обмеженнях $\sum_{i} a_{i} x_{i} \geq A_{1}$.

Це задача «пакування рюкзака», що ефективно вирішується методом дихотомічного програмування при цілочислових значеннях параметрів. На Рисунку 1 наведено структуру дихотомічного подання задачі. Вершини $x_{1}-x_{6}$ відповідають набору заходів. У вершинах $y_{1}-y_{5}$ відбувається матрична згортка відповідних показників нижнього рівня.

Розв’язуючи такого типу задачі для кожного чинника, отримуємо витрати $c^{\mathrm{B}}{ }_{i j}$, необхідні для зниження ймовірності від високого рівня до рівня $j=1,2,3$.

При цьому величина $c^{\text {в }}$ вз відповідає витратам на збереження високого рівня ризику (не допустити катастрофи).

Аналогічні задачі розв'язуються для визначення мінімальної величини витрат $c_{i j}^{y}$, необхідних для зниження величини збитку до мінімального або середнього рівня.

Процедура зниження ризику:

1. Визначаємо мінімальні витрати на досягнення кожної з інтегральних оцінок за допомогою матричної згортки. Перше число в матриці - величина оцінки, друге - витрати на досягнення (або збереження) цієї оцінки. Рухаючись знизу догори, отримуємо для кожної інтегральної оцінки мінімальні витрати (на зменшення ступеню небезпеки від високого до середнього і низького). Для цього із клітинок матриці з однаковими оцінками (перше число) вибираємо клітинку з мінімальними витратами.

2. Формування сукупності оцінок факторів, що забезпечують необхідне значення інтегральної оцінки 3 мінімальними витратами, відбувається методом зворотного ходу. Для цього послідовно, згори донизу, визначаємо, які вихідні дані відповідають вибраній клітинці матриці. Встановивши ці значення знаходимо їх у матрицях нижнього рівня.

Повторюємо це доти, поки не досягнемо нижнього рівня структури дихотомічного подання, тобто конкретних оцінок факторів ризику. Набір цих оцінок є результатом дії процедури.

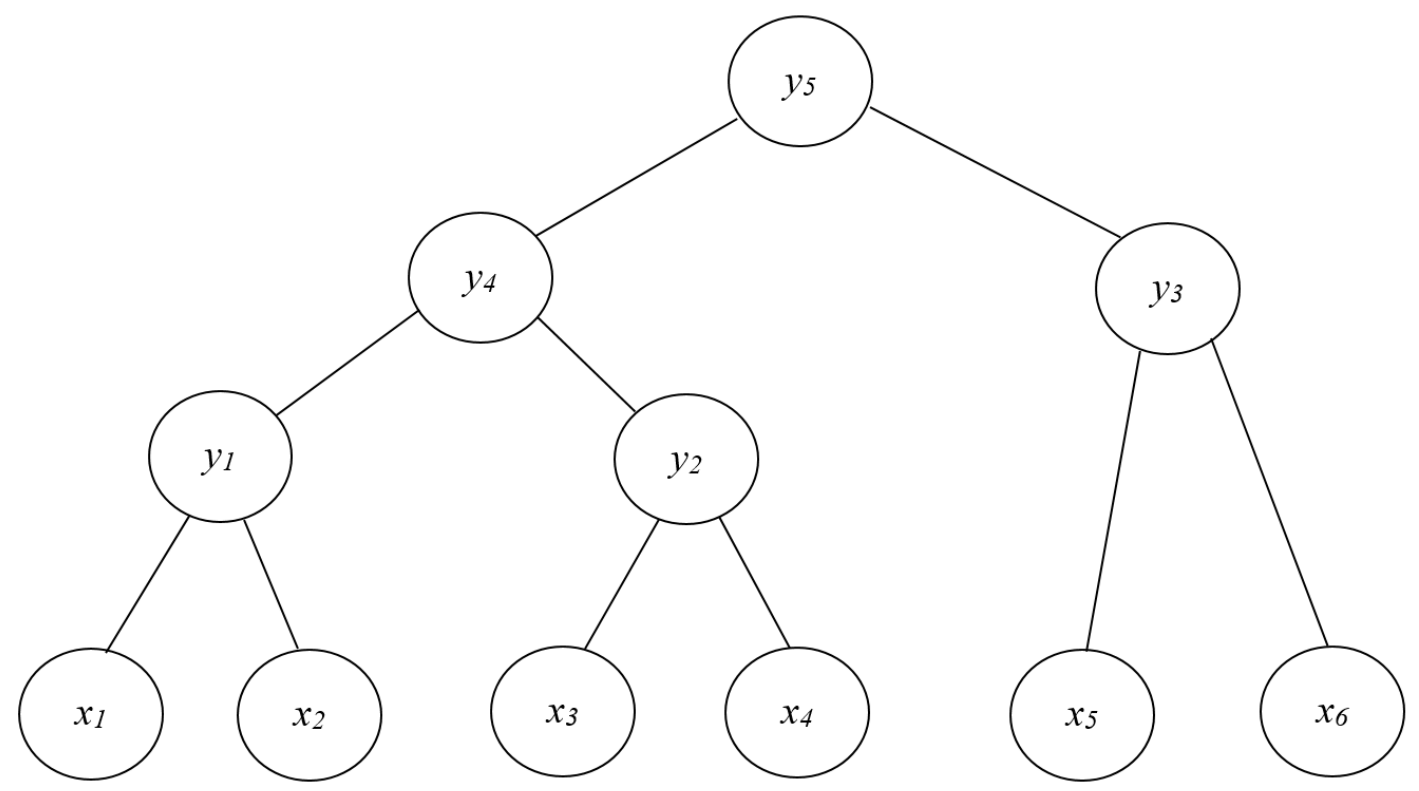

Рисунок 1. Структура дихотомічного подання задачі 


\section{4. РЕЗУЛЬТАТИ}

Результати структурованої оцінки ризику. Забезпечення проведення ідентифікації небезпек та оцінки ризиків забезпечується керівниками структурних підрозділів підприємства увідповідному структурному підрозділі для визначення результативності заходів з охорони праці, що були вжиті стосовно управління ризиками та встановлення нових.

На підставі аналізу реєструвстановлено ряд небезпек, що мають найвищі значення ризикута зустрічаються найчастіше (Рисунок 2), класифікація яких наведена в Таблиці 6.

Таким чином, ризиками, що можливі найчастіше, є: травмування від обладнання, що рухається (39\%); травмування від падіння з висоти (17\%); травмування від дії електричного струм (15\%). Але найбільшу тяжкість мають небезпеки, що пов’язані з отруєнням.

Таблиця 6. Класифікація виробничих ризиків підприємства

\begin{tabular}{|c|c|c|c|c|c|}
\hline \multicolumn{6}{|c|}{ Вид ризику } \\
\hline $\begin{array}{l}\text { Травмування від } \\
\text { падіння } 3 \text { висоти }\end{array}$ & $\begin{array}{c}\text { Травмування } \\
\text { від обладнання, } \\
\text { що рухається }\end{array}$ & $\begin{array}{c}\text { Травмування } \\
\text { від вибуху, } \\
\text { пожежі }\end{array}$ & $\begin{array}{l}\text { Травмування від } \\
\text { дії електричного } \\
\text { струму }\end{array}$ & Отруєння & $\begin{array}{l}\text { Термічні та } \\
\text { хімічні опіки }\end{array}$ \\
\hline \multicolumn{6}{|c|}{ Причини появи небезпеки } \\
\hline $\begin{array}{l}\text { 1. Розташування } \\
\text { робочого місця } \\
\text { на значній висоті } \\
\text { відносно поверхні } \\
\text { землі (підлоги). }\end{array}$ & $\begin{array}{l}\text { 1. Інструмент, що } \\
\text { ріже та рухається. } \\
\text { 2. Рухомі частини } \\
\text { виробничого } \\
\text { обладнання, } \\
\text { матеріали, що } \\
\text { рухаються. }\end{array}$ & $\begin{array}{l}\text { 1. Поява іскри. } \\
\text { 2. Дія шуму та } \\
\text { вібрацій. }\end{array}$ & $\begin{array}{l}\text { 1. Підвищення } \\
\text { напруги в } \\
\text { електричній мережі. } \\
\text { 2. Струм, який може } \\
\text { пройти крізь тіло } \\
\text { людини. }\end{array}$ & $\begin{array}{l}\text { 1. Вплив шкідливих } \\
\text { речовин. } \\
\text { 2. Контакт із діючою } \\
\text { речовиною. } \\
\text { 3. Підвищена } \\
\text { загазованість та } \\
\text { запиленість повітря } \\
\text { робочої зони. }\end{array}$ & $\begin{array}{l}\text { 1. Вплив нагрітих } \\
\text { поверхонь } \\
\text { металів. } \\
\text { 2. Пара та } \\
\text { розлітання } \\
\text { крапель кислот. }\end{array}$ \\
\hline \multicolumn{6}{|c|}{ Види робіт та обладнання } \\
\hline $\begin{array}{l}1 . \\
\text { Розвантажувально- } \\
\text { навантажувальні } \\
\text { роботи на кранах. } \\
\text { 2. Прибирання снігу } \\
\text { на дахах. }\end{array}$ & $\begin{array}{l}\text { 1. Робота на } \\
\text { металообробному } \\
\text { обладнанні. } \\
2 . \\
\text { Навантажувально- } \\
\text { розвантажувальні } \\
\text { роботи. }\end{array}$ & $\begin{array}{l}\text { 1. Робота з } \\
\text { обладнанням для } \\
\text { газонебезпечних } \\
\text { робіт. } \\
\text { 2. Виробниче } \\
\text { обладнання } \\
\text { дробометання. }\end{array}$ & $\begin{array}{l}\text { 1. Робота на діючих } \\
\text { електроустановках. } \\
\text { 2. Технологічне } \\
\text { та зварювальне } \\
\text { обладнання. } \\
\text { 3. Вантажопідйомні } \\
\text { машини. } \\
\text { 4. Монтажні та } \\
\text { обслуговуючі } \\
\text { роботи. }\end{array}$ & $\begin{array}{l}\text { 1. Гальванічні } \\
\text { роботи. } \\
\text { 2. Нанесення } \\
\text { лакофарбового } \\
\text { покриття. } \\
\text { 3. Робота з } \\
\text { обладнанням для } \\
\text { термічних робіт. } \\
\text { 4. Робота з } \\
\text { легкозаймистими } \\
\text { речовинами. }\end{array}$ & $\begin{array}{l}\text { 1. Виробниче } \\
\text { гальванічне } \\
\text { обладнання. } \\
\text { 2. Роботи з } \\
\text { обслуговування } \\
\text { та ремонту } \\
\text { технологічного } \\
\text { обладнання. }\end{array}$ \\
\hline \multicolumn{6}{|c|}{ Заходи захисту } \\
\hline $\begin{array}{l}\text { 1. Облаштування } \\
\text { робочого місця } \\
\text { захисною огорожею. } \\
\text { 2. Знаки безпеки. } \\
\text { 3. Робота на } \\
\text { драбині із } \\
\text { запобіжним поясом. } \\
\text { 4. Знаки безпеки. }\end{array}$ & $\begin{array}{l}\text { 1. Використання } \\
\text { захисної огорожі. } \\
\text { 2. Знаки безпеки. }\end{array}$ & $\begin{array}{l}\text { 1. Робота } \\
\text { в засобах } \\
\text { індивідуального } \\
\text { захисту (ЗІ3). } \\
\text { 2. Знаки безпеки. }\end{array}$ & $\begin{array}{l}\text { 1. Перевірка опору } \\
\text { електричної мережі, } \\
\text { опору ізоляції, } \\
\text { заземлення. } \\
\text { 2. Занулення, } \\
\text { застосування } \\
\text { кабелю із подвійною } \\
\text { ізоляцією. } \\
\text { 3. Знаки безпеки. } \\
\text { 4. Робота в ЗІЗ. }\end{array}$ & $\begin{array}{l}\text { 1. Облаштування } \\
\text { витяжної вентиляції. } \\
\text { 2. 3І3. }\end{array}$ & $\begin{array}{l}\text { 1. Використання } \\
\text { вентиляції. } \\
\text { 2. Знаки безпеки. } \\
\text { 3. ЗІ3. }\end{array}$ \\
\hline
\end{tabular}

Результати комплексного оцінювання та визначення інтегральної оцінки ризику полягають у наступному. Розглядаємо матрицю визначення рівня небезпеки в залежності від рівня ймовірності ті рівня збитку. У кожній клітинці матриці записуємо суму мінімальних витрат. Із усіх клітинок з однаковими рівнями ступеню небезпеки вибираємо клітинку з мінімальною сумою. В результаті отримуємо таблицю мінімальних витрат, необхідних на зменшення ступеню небезпеки від максимального до мінімального та середніх рівнів.

Є 6 заходів, дані про які наведено у Таблиці 7. 


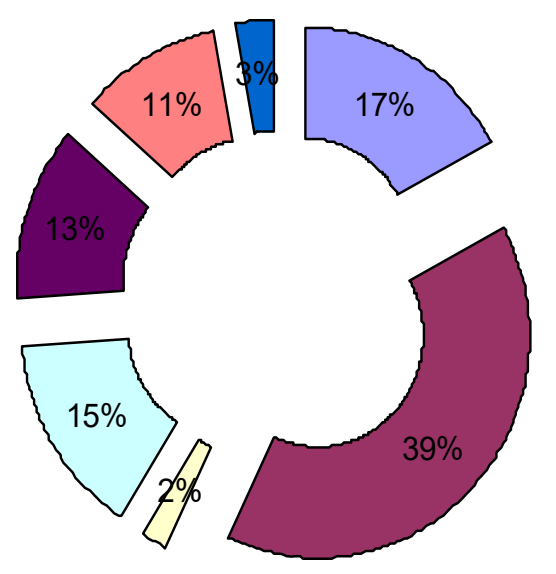

$\square$ Травмування від падіння з висоти

$\square$ Травмування від обладнання що рухається

$\square$ Травмування від вибуху, пожежі

$\square$ Травмування від дії електричного струму

Отруєння

Термічні та хімічні опіки

Інші небезпеки

Рисунок 2. Розподіл видів ризиків на підприємстві

Таблиця 7. Заходи з охорони праці та відповідні витрати

\begin{tabular}{l|l|l|l|l|l}
\hline & \multicolumn{3}{c}{ Заходи зі зменшення ризику, $\boldsymbol{i}$} \\
\hline Зменшення імовірності, $a_{i}$ & 1 & 2 & 1 & 3 & 2 \\
\hline Витрати, $b_{i}$ & 9 & 16 & 7 & 18 & 18 \\
\hline
\end{tabular}

Нехай $A_{1}=0,7$ та $A_{2}=0,4$. Задача полягає у мінімізації $B(x)=9 x_{1}+16 x_{2}+7 x_{3}+18 x_{4}+18 x_{5}+4 x_{6}$ при обмеженнях $x_{1}+2 x_{2}+x_{3}+3 x_{4}+2 x_{5}+x_{6} \geq 7$.

Візьмемо структуру дихотомічного подання задачі, наведену на Рисунку 1.

Перший крок. Розв'язуємо задачу для заходів 1 та 2. Розв’язок наведено в Таблиці 8. Перше число у клітинці дорівнює зменшенню ймовірності (ефект), а друге - витратам. Результати зведені в Таблиці 9.

Таблиця 8. Розв'язок задачі

\begin{tabular}{l|c|c|c}
1 & $2 ; 16$ & $3 ; 25$ \\
\hdashline & $0 ; 0$ & $1 ; 9$ \\
\hdashline & 0 & 1 \\
\hline
\end{tabular}

Таблиця 9. Зведені результати

\begin{tabular}{|c|c|c|c|c|}
\hline № варіанту & 0 & 1 & 2 & 3 \\
\hline Ефрект & 0 & 1 & 2 & 3 \\
\hline Витрати & 0 & 9 & 16 & 25 \\
\hline
\end{tabular}

Другий крок. Розв’язуємо задачу для заходів 3 та 4. Результати наведено в Таблиці 10 та зведено в Таблиці 11.

Таблиця 1о. Розв’язок задачі

\begin{tabular}{llll}
1 & $3 ; 18$ & $4 ; 25$ \\
\hline 0 & $0 ; 0$ & $1 ; 7$ \\
\hline 2 & 1 & 0 & 1 \\
\hline
\end{tabular}

Таблиця 11. Зведені результати

\begin{tabular}{|c|c|c|c|c|}
\hline № варіанту & 0 & 1 & 2 & 3 \\
\hline Ефект & 0 & 1 & 3 & 4 \\
\hline Витрати & 0 & 7 & 18 & 25 \\
\hline
\end{tabular}

Третій крок. Розв’язуємо задачу для заходів 5 та 6. Результати наведено в Таблиці 12 та зведено в Таблиці 13.

Таблиця 12. Розв’язок задачі

\begin{tabular}{|c|c|c|}
\hline 1 & $1 ; 4$ & $3 ; 22$ \\
\hline 0 & $0 ; 0$ & $2 ; 18$ \\
\hline $2 \quad 1$ & 0 & 1 \\
\hline
\end{tabular}

Таблиця 13. Зведені результати

\begin{tabular}{llll:l} 
№ варіанту & 0 & 1 & 2 & 3 \\
\hdashline Ерект & 0 & 1 & 2 & 3 \\
\hdashline Витрати & 0 & 4 & 18 & 22 \\
\hline
\end{tabular}


Четвертий крок. Розв’язуємо задачу для об’єднаних заходів $(1,2)$ та $(3,4)$. Результати наведено в Таблиці 14 та зведено в Таблиці 15.

Таблиця 14. Розв’язок задачі

\begin{tabular}{|c|c|c|c|c|}
\hline 3 & $4 ; 25$ & $5 ; 34$ & $6 ; 41$ & $7 ; 50$ \\
\hline 2 & $3 ; 18$ & $4 ; 27$ & $5 ; 34$ & $6 ; 43$ \\
\hline 1 & $1 ; 7$ & $2 ; 16$ & $3 ; 23$ & $4 ; 32$ \\
\hline 0 & $0 ; 0$ & $1 ; 9$ & $2 ; 16$ & $3 ; 25$ \\
\hline & 0 & 1 & 2 & 3 \\
\hline
\end{tabular}

Таблиця 15. Зведені результати

\begin{tabular}{ll:l:lll:lll:l} 
№ варіанту & 0 & 1 & 2 & 3 & 4 & 5 & 6 & 7 \\
\hdashline Ефект & 0 & 1 & 2 & 3 & 4 & 5 & 6 & 7 \\
\hdashline Витрати & 0 & 7 & 16 & 18 & 25 & 34 & 41 & 50 \\
\hline
\end{tabular}

П’ятий крок. Розв’язуємо задачу для об’єднаних заходів $(1,2,3,4)$ та (5,6). Результати наведено в Таблиці 16.

Таблиця 16. Розв’язок задачі

\begin{tabular}{|c|c|c|c|c|c|c|c|c|}
\hline 3 & $3 ; 22$ & $4 ; 29$ & $5 ; 38$ & $6 ; 40$ & $7 ; 47$ & - & - & - \\
\hline 2 & $2 ; 18$ & $3 ; 25$ & $4 ; 34$ & $5 ; 36$ & $6 ; 43$ & $7 ; 52$ & - & - \\
\hline 1 & $1 ; 4$ & $2 ; 11$ & $3 ; 20$ & $4 ; 22$ & $5 ; 29$ & $6 ; 38$ & $7 ; 45$ & - \\
\hline 0 & $0 ; 0$ & $1 ; 7$ & $2 ; 16$ & $3 ; 18$ & $4 ; 25$ & $5 ; 34$ & $6 ; 41$ & $7 ; 50$ \\
\hline & 0 & 1 & 2 & 3 & 4 & 5 & 6 & 7 \\
\hline
\end{tabular}

Оптимальному рішенню відповідає клітинка (7;45). Для визначення рішення застосовуємо метод зворотного ходу. Клітці (7;45) відповідає варіант 6 Таблиці 15 та варіант 1 Таблиці 14.

Варіанту 6 Таблиці 15 відповідає клітинка (6;41). Клітинці (6;41) Таблиці 14 відповідає варіант 3 Таблиці 11 та варіант 2 Таблиці 9. Варіанту 3 Таблиці 11 відповідає клітинка $(4 ; 25)$ Таблиці 10, що визначає значення змінних $x_{3}=1, x_{4}=1$.

Варіанту 2 Таблиці 9 відповідає клітинка $(2 ; 16)$ Таблиці 8 , що визначає значення змінних $x_{1}=0, x_{2}=1$.

Варіанту 1 Таблиці 13 відповідає клітинка $(1 ; 4)$ Табл.иці12, що визначає значення змінних $x_{5}=0, x_{6}=1$. Остаточно отримуємо рішення: $x_{1}=0, x_{2}=1, x_{3}=1, x_{4}=1, x_{5}=0, x_{6}=1$, яке забезпечує зниження ймовірності на 0.7 з мінімальними витратами 45.

Відмітимо, що одночасно вирішено задачу зменшення імовірності, достатньої для переводу відповідного критерію із середнім ризиком. Дійсно, оптимальному рішенню в цьому випадку відповідає клітинка (4;22) Таблиці 16. Цій клітинці відповідає варіант 3 Таблиці 15 та варіант 1 Таблиці 13. Варіанту 1 Таблиці 13 відповідає клітинка $(1 ; 4)$ Таблиці 12 , тобто $x_{5}=0$ та $x_{6}=1$. Варіанту 3 Таблиці 15 відповідає клітинка (3;25) Таблиці 14. Цій клітинці, в свою чергу, відповідає варіант 2 Таблиці 11 та варіант 0 Таблиці 9, тобто, $x_{1}=0, x_{2}=0, x_{3}=0, x_{4}=1$.

Остаточно отримуємо рішення: $x_{1}=0, x_{2}=0, x_{3}=0, x_{4}=1, x_{5}=0, x_{6}=1$, яке дає зменшення ймовірності 0.43 мінімальними витратами 22.

Для побудови системи комплексного оцінювання для визначення інтегральної оцінки ризику (ступеню небезпеки ризикової події) побудуємо дерево згортки показників (Рисунок 3).

Для початку об’єднаємо травмування від падіння з висоти та травмування від обладнання що рухається (I) та травмування від вибуху, пожежі і травмування від дії електричного струму (II), які об’єднуються в ризики механічного впливу (III). Потім об’єднаємо отруєння і термічні та хімічні опіки (IV). Нарешті, об’єнуємо механічні та термохімічні ризики $(\mathrm{V})$ та отримуємо інтегральну оцінку зниження небезпеки. 


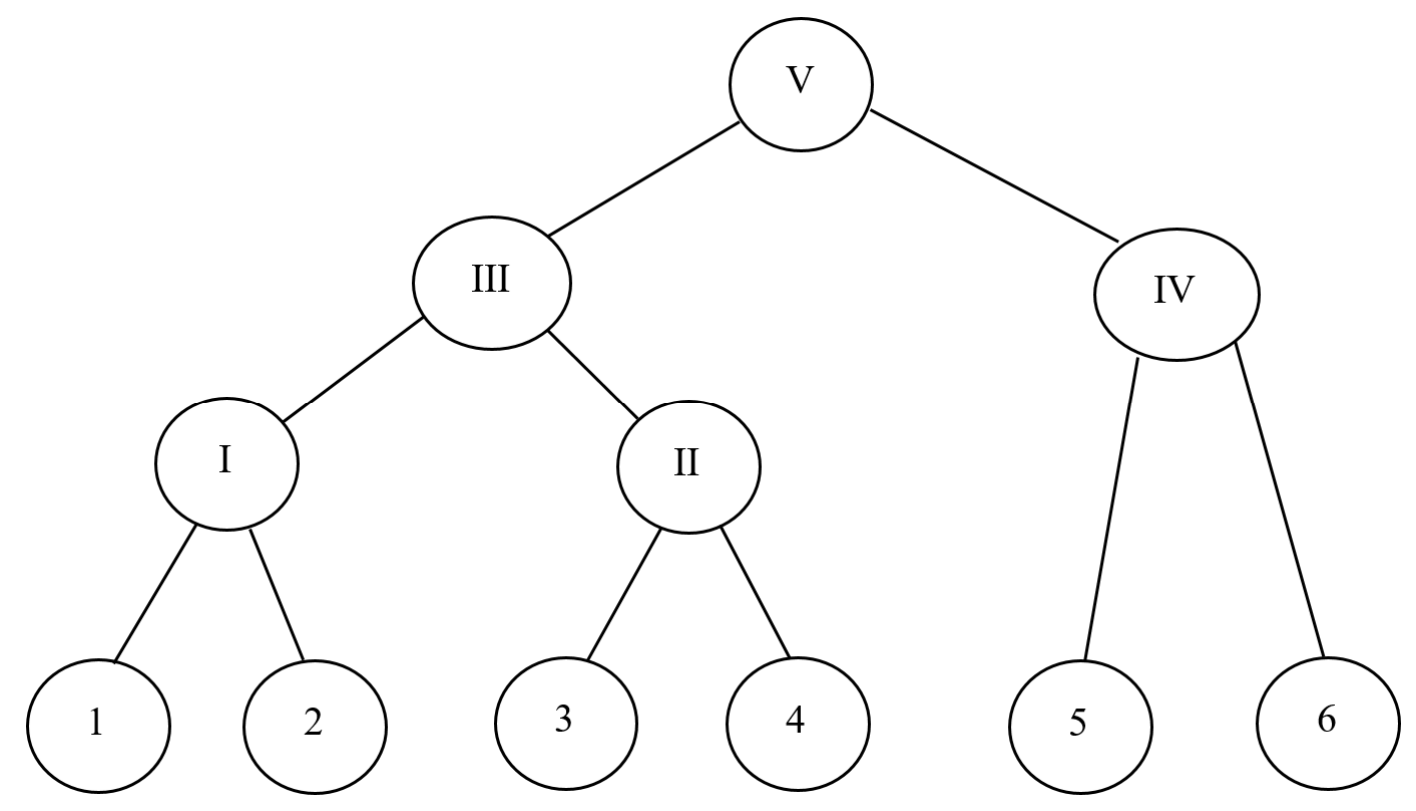

Рисунок 3. Дерево згортки показників ризику

\section{ВИСНОВКИ}

В результаті ідентифікації та аналізу існуючих ризиків на ДП «Завод «Електроважмаш», що були здійснені з використанням методу структурованої оцінки встановлено, що ризиками, що можливі найчастіше, $\epsilon$ травмування від обладнання, що рухається (39\%), травмування від падіння з висоти (17\%), травмування від дії електричного струм (15\%); отруєння є небезпекою, що має найбільшу тяжкість.

Процедура інтегральної оцінки ризику на основі моделі «пакування рюкзака» полягає у визначанні мінімальних витрат на досягнення кожної з інтегральних оцінок за допомогою матричної згортки. Ця оптимізаційна задача ефективно вирішується методом дихотомічного програмування при цілочислових значеннях параметрів. Розглядаються матриці, в яких одне число - величина оцінки, інше - витрати на досягнення цієї оцінки. Перебираючи значення від нижніх до верхніх, отримуємо для кожної інтегральної оцінки мінімальні витрати. Знаходження сукупності оцінок факторів, необхідних для забезпечення необхідних значень інтегральної оцінки з мінімальними витратами, відбувається згори до низу. Отримані значення знаходяться у матрицях нижнього рівня і є результатом дії процедури.

\section{СПИСОК ЛІТЕРАТУРИ}

1. Abrakytov, V. E., \& Faryna, Y. А. (2013). Современное состояние вопроса оценки риска аварий кранових канатов [Sovremennoe sostoyanye voprosa otsenky ryska avaryy kranovykh kanatov]. Komunalne hospodarstvo mist, 109, 209-212.

2. Aleksandrikova, I. O., \& Korzhyk, B. М. (2007). Характеристика методів аналізу ризику небезпечних промислових об'єктів [Кharakterystyka metodiv analizu ryzyku nebezpechnykh promyslovykh obyektiv]. Budivnytstvo, materialoznavstvo, mashynobuduvannya, 40, 212-215. Retrieved from http://eprints.kname.edu.ua/43049/1/24._Harakteristika_metodiv.PDF

3. Avtukhov, K., Mukanova, A., Sorokin, O., \& Yakovets, I. (2016). Альтернативна доповідь про виконання Україною Європейської соціальної хартії (переглянутої) [Alternatyvna dopovid pro vykonannia Ukrainoiu Yevropeiskoi sotsialnoi khartii (perehlianutoi)] (56 p.). Ukrainska Helsinska spilka z prav liudyny. Retrieved from https://helsinki.org.ua/wp-content/uploads/2017/02/AlternativeReport-ESCR-19.12_ukr.pdf

4. Barkalov, S. A., Burkov, V. N., \& Kireyeva, Ye. А. (2013). Построение системы комплексного оценивания для определения интегральной оценки риска [Postroenye systemy kompleksnoho otsenyvanyya dlya opredelenyya yntehralnoy otsenky ryska]. Ekonomika i menedzhment sistem upravleniya, 4(10), 10-16.

5. Bashynska, I. O., Poleshchuk, A. A. \& Motova, A. V. (2017). Удосконалення системи управління ризиками на підприємстві [Udoskonalennia systemy upravlinnia ryzykamy na pidpryiemstvi]. Prychornomorski ekonomichni studii, 17, 91-94. Retrieved from http://dspace. opu.ua/jspui/handle/123456789/3975 
6. Baskakov, V. P., Efymov, V. Y., \& Senatorov, H. V. (2011). Оценка рисков аварий, инцидентов и несчастных случаев. Планы управления безопасностью труда [Otsenka riskov avariy, intsidentov i neschastnykh sluchayev. Plany upravleniya bezopasnostyu truda]. Izvestiya Tulskogo gosudarstvennogo universiteta. Nauki o zemle, 1, 22-35. Retrieved from https://cyberleninka.ru/article/n/otsenkariskov-avariy-intsidentov-i-neschastnyh-sluchaev-plany-upravleniya-bezopasnostyu-truda

7. Bezsonnyi, V. L. (2018). Виробничі ризики та менеджмент безпеки праці на машинобудівному підприємстві [Vyrobnychi ryzyky ta menedzhment bezpeky pratsi na mashynobudivnomu pidpryyemstvi]. In Bezpeka lyudyny u suchasnykh umovakh: materialy XII mizhnarodnoyi naukovo-metodychnoyi konferentsiyi ta mizhnarodnoyi konferentsiyi EAS (6-7 hrudnya 2018 r.) (pp. 51-53). Kharkiv: NTU «KHPI».

8. Bezsonnyi, V. L. (2018). Математичне моделювання при забезпеченні безпечних умов праці [Matematychne modelyuvannya pry zabezpechenni bezpechnykh umov pratsi]. In Bezpeka zhyttya i diyalnosti lyudyny - osvita, nauka, praktyka: materialy Mizhnarodnoyi naukovo-metodychnoyi konferentsiyi (pp. 101-102). Retrieved from http://iept.lpnu.ua/images/cb/zbirnyk_bzhdl_2018.pdf

9. Bezsonnyi, V. L. (2018). Оцінка ризиків техногенних аварій [Otsinka ryzykiv tekhnohennykh avarii]. In Tekhnohenno-ekolohichna bezpeka Ukrayiny: stan ta perspektyvy rozvytku: materialy VIII Vseukrainskoi naukovo-praktychnoi Internet-konferentsii (Irpin, 12-20 lystopada, 2018 r.) (pp. 225-228). Irpin: Natsionalnyi universytet DFS Ukrainy.

10. Bezsonnyi, V. L. (2018). Оцінка ризику на робочому місці як основний інструмент управління безпекою праці [Otsinka ryzyku na robochomu mistsi yak osnovnyi instrument upravlinnia bezpekoiu pratsi]. In Aktualni pytannia tekhnohennoi ta tsyvilnoi bezpeky Ukrainy: materialy I Vseukrainskoi naukovoi konferentsii (pp. 198-200). Mykolayiv: Torubara V.V.P.

11. Burkov, V. N., Gratsianskiy, Ye. V., Dzyubko, S. I., \& Shchepkin, A. V. (2001). Модели и механизмы управления безопасностью [Модеly y mekhanyzmy upravlenyya bezopasnostyu] (140 p.). Moskva: SYNTEH. Retrieved from http://www.mtas.ru/upload/library/Security.pdf

12. Denysenko, V. Y., \& Dyachenko, A. Р. (2008). Охорона праці у машинобудівному виробництві [Otsenka proyzvodstvennoho ryska na mashynostroytelnykh predpryyatyyakh]. Problemy analyza ryska, 5(3), 22-38.

13. Didenko, Ye. V. (2017). Модель оцінки ризиків виробничого травматизму [Model otsinky ryzykiv vyrobnychoho travmatyzmu]. Suchasnyi stan naukovykh doslidzhen ta tekhnolohii v promyslovosti, 1(1), 28-33. Retrieved from http://nbuv.gov.ua/UJRN/dtssi_2017_1_7

14. DNAOP (2010). ДСТУ OHSAS 18001:2010. Системи управління гігієною та безпекою праці [DSTU OHSAS 18001:2010. Systemy upravlinnia hihiienoiu ta bezpekoiu pratsi]. Retrieved from https://bitly.su/zXE8DeFp

15. DSTU OHSAS 18001-99 (1999). Системи управління охороною здоров'я і безпекою персоналу [Systemy upravlinnia okhoronoiu zdorovia i bezpekoiu personalu].

16. DSTU OHSAS 18002:2015 (2015). Рекомендащї по упровадженню OHSAS 18001 [Rekomendatsii ро uprovadzhenпіи OHSAS 18001].

17. Heinrich, H. W. (1959). Industrial accident prevention a scientific approach (480 p.). New York: McGraw-Hill.

18. Hlyva, V. A., Berezutskyi, V. V., Berezutska, N. L., \& Khalil, V. V. (2016). Аудит ризиків безпеки на робочому місці [Аudyt ryzykiv bezpeky na robochomu mistsi]. Tekhnologicheskiy audit i rezervy proizvodstva, 2(3), 12-17. Retrieved from http://nbuv.gov.ua/UJRN/ Tatrv_2016_2(3)_4

19. Hofreiter, L., \& Simko, J. (2007). Zdroje a oblasti konfliktov sucasneho sveta (95 p.). Liptovsky Mikulas: Akademia ozbrojenych sil generala Milana Rastislava Stefanika.

20. Holubenko, O. L. et al. (2010). Охорона пращі у машинобудівному виробнищтві [Okhorona pratsi u mashynobudivnomu vyrobnytstvi] (456 p.). Luhansk: Skhidnoukrainskyi natsionalnyi universytet im. V. Dalia.

21. ISO 14001:2004 (2004). Системы экологического менеджмента. Требования и руководство по применению [Sistemy ekologicheskogo menedzhmenta. Trebovaniya i rukovodstvo po primeneniyu].

22. ISO 9001:2000 (2000). Системи управління якістю вимоги [Systemy upravlinnia yakistiu vymohy].

23. Korzeniowski, L. F. (2011). Podstawy zarządzania organizacjami (183 p.). Warszawa: Difin.

24. Kostenko, О. М. (2002). Удосконалення методів і засобів з комплексного аналізу, прогнозу та попередження виробничого травматизму у сільськогосподарському виробництві [Udoskonalennia metodiv i zasobiv z kompleksnoho analizu, prohnozu ta poperedzhennia vyrobnychoho travmatyzmu u silskohospodarskomu vyrobnytstvi] (24 p.) (Extended abstract of Ph.D. thesis). Kyiv: Natsionalnyi naukovo-doslidnyi instytut okhorony pratsi.

25. Laktionov, S. O., \& Sieriko, Ya. О. (2015). Виробничий травматизм і професійна захворюваність як проблема сучасності: аспекти, причини, шляхи запобігання [Vyrobnychyi travmatyzm i profesiina zakhvoriuvanist yak problema suchasnosti: aspekty, prychyny, shliakhy zapobihannia]. In Bezpeka lyudyny u suchasnykh umovakh: mizhnarodna konferentsiya (pp. 219-224.). Kharkiv: NTU «KHPI». Retrieved from https://bitly.su/Dy77O

26. Lys, Yu. S. (2016). Оцінка ризиків в системі управління охороною праці [Otsinka ryzykiv v systemi upravlinnia okhoronoiu pratsi]. Systemy obrobky informatsii, 9(146), 193-196. Retrieved from http://nbuv.gov.ua/UJRN/soi_2016_9_40

27. Tairova, T. M., \& Malykhin, O. V. (2015). Закордонний досвід державного нагляду з промислової безпеки та охорони праці [Zakordonnyi dosvid derzhavnoho nahliadu z promyslovoi bezpeky ta okhorony pratsi]. Informatsiinyi biuleten z okhorony pratsi, 2, 59-68.

28. The Verkhovna Rada of Ukraine (2018). Закон України «Про охорону праці» [Zakon Ukrainy «Pro okhoronu pratsi»]. Retrieved from https://zakon.rada.gov.ua/laws/show/2694-12

29. Tkachenko, I. V., \& Shparka, I. I. (2013). Виробничий травматизм - проблема сучасності: актуальні аспекти, причини та шляхи запобігання [Vyrobnychyi travmatyzm - problema suchasnosti: aktualni aspekty, prychyny ta shliakhy zapobihannia]. Visnyk Chernivetskoho torhovelno-ekonomichnoho instytutu. Ekonomichni nauky, 2, 375-381. Retrieved from http://nbuv.gov.ua/UJRN/Vchtei_2013_2_71

30. Tkachuk, K. N., \& Kruzhylko, О. Үе. (2014). Прогнозування виробничого травматизму [Prohnozuvannya vyrobnychoho travmatyzmи] (345 p.). Kyyiv: Osnova.

31. Tkachuk, K. N., \& Tairova, T. M. (2013). Математична модель прогнозування стану безпеки праці [Matematychna model prohnozuvannia stanu bezpeky pratsi]. Visnyk Natsionalnoho universytetu vodnoho hospodarstva ta pryrodokorystuvannia, 1(61), 273-279. Retrieved from http://ep3.nuwm.edu.ua/1057

32. Tretiakov, O. V., Kharchenko, I. P., \& Pikhota, Ya. S. (2015). Підвищення достовірності показників статистичного методу оцінки виробничого травматизму [Pidvyshchennia dostovirnosti pokaznykiv statystychnoho metodu otsinky vyrobnychoho travmatyzmu]. Komunalne hospodarstvo mist, 120(1), 69-74. Retrieved from https://khg.kname.edu.ua/index.php/khg/article/ view/4843/4801 
33. Vetoshkin, A. H., \& Tarantseva, K. R. (2001). Техногенный риск и безопасность [Tekhnohennyy rysk y bezopasnost] (171 p.). Penza: Penzenskiy gosudarstvennyy universitet.

34. Vitkin, L. M., \& Rolko, O. R. (2016). Ризики в системах управління [Ryzyky v systemakh upravlinnia]. Systemy obrobky informatsii, 3 , 203-208. Retrieved from http://nbuv.gov.ua/UJRN/soi_2016_3_48

35. Voloshin, V. S., Elistratova, N. Yu., \& Burco, V. A. (2017). Оценка рисков безопасности труда на металлургическом предприятии [Otsenka riskov bezopasnosti truda na metallurgicheskom predpriyatii]. Vestnik Priazovskogo gosudarstvennogo tekhnicheskogo universiteta. Seriya: Tekhnicheskiye nauki, 35, 257-263. Retrieved from https://cyberleninka.ru/article/n/otsenka-riskov-bezopasnosti-trudana-metallurgicheskom-predpriyatii

36. Zaporozhets, O. I. (2007). Щодо проекту концепції управління ризиками надзвичайних ситуацій техногенного і природного характеру [Shchodo proektu kontseptsii upravlinnia ryzykamy nadzvychainykh sytuatsii tekhnohennoho i pryrodnoho kharakteru]. In Bezpeka zhyttya i diyalnosti lyudyny - osvita, nauka, praktyka (pp. 10-12). Kyiv: Samit-Knyha.

37. Zelenskyy, I. (2011). Приховування нещасних випадків як засіб поліпшення статистики [Prykhovuvannia neshchasnykh vypadkiv yak zasib polipshennia statystyky]. Okhorona pratsi, 6, 34-35. Retrieved from http://ohoronapraci.kiev.ua/ru/arhiv-zhurnala 